\title{
BMJ Open Smoking prevalence and attitudes towards smoking among Estonian physicians: results from cross-sectional studies in 2002 and 2014
}

\author{
Mariliis Põld, Kersti Pärna
}

To cite: Põld M, Pärna K. Smoking prevalence and attitudes towards smoking among Estonian physicians: results from cross-sectional studies in 2002 and 2014. BMJ Open 2017;7:e017197. doi:10.1136/ bmjopen-2017-017197

- Prepublication history for this paper is available online. To view these files, please visit the journal online (http://dx.doi org/10.1136/bmjopen-2017017197).

Received 6 April 2017

Revised 2 September 2017

Accepted 13 September 2017

CrossMark

Institute of Family Medicine and Public Health, University of Tartu, Tartu, Estonia

Correspondence to

Mariliis Põld;

pold.mariliis@gmail.com

\section{ABSTRACT}

Objectives To explore smoking prevalence and attitudes towards smoking among Estonian physicians in 2002 and 2014.

Design Two self-administered cross-sectional postal surveys were conducted among practising physicians in Estonia.

Participants Initial sample consisted of all practising physicians in Estonia. The corrected response rate was $67.8 \%$ in 2002 and $53.1 \%$ in 2014. Present study sample was restricted to physicians younger than 65 years ( $n=2549$ in 2002, $n=2339$ in 2014).

Methods Age-standardised prevalence of smoking and prevalence of agreement with seven statements concerning attitudes towards smoking was determined. To analyse association of physicians' attitudes towards smoking with study year and smoking status, logistic regression analysis was used. Adjusted ORs of agreement with the seven statements were determined. Corresponding $95 \%$ Cls were calculated.

Results The age-standardised prevalence of current smoking among men was $26.8 \%$ in 2002 and $15.3 \%$ in 2014 , among women $10.4 \%$ and $5.8 \%$, respectively. Compared with the year 2002, in 2014, prevalence of agreement with statements declaring harmfulness of smoking was higher and prevalence of agreement with statements approving smoking was lower. Adjusted ORs showed that compared with 2002, physicians' attitudes towards smoking were less favourable in 2014, and physicians' attitudes towards smoking were associated with their smoking status.

Conclusions Compared with 2002, the age-standardised smoking prevalence among male and female physicians was lower, and attitudes towards smoking were less approving in 2014. The smoking physicians had more approving attitudes towards smoking than their non-smoking colleagues.

\section{INTRODUCTION}

Smoking is among the leading preventable causes of death and is considered a major public health threat. According to WHO, among adults aged 30 years and over, 12\% of all deaths are attributed to tobacco. ${ }^{1}$ Reducing smoking will result in fewer deaths
Strengths and limitations of this study

The surveys were nationwide, initially involving all practising physicians in Estonia.

- Changes in smoking prevalence were easily comparable due to similar methods and questionnaires used in 2002 and 2014.

- The surveys relied on self-reported data and therefore the bias of self-representation should be considered.

- In terms of response rates, the possibility that smokers prevail among persistent non-respondents may have led to the underestimation of smoking prevalence rates.

and less diseases like lung cancer, heart diseases, stroke, chronic respiratory diseases and other conditions. ${ }^{2}$

Physicians are generally regarded as people from whom smokers would accept advice on smoking cessation. ${ }^{3}$ However, physicians' smoking status could affect their attitudes towards smoking and their enthusiasm in addressing patients' smoking. ${ }^{45}$

Smoking behaviour among physicians has been studied for decades. British male doctors smoking cohort study is the most commonly known and began in $1951 .^{6}$ In the developed countries (eg, USA, Australia, Finland and Denmark), smoking among physicians has declined during the last decades, ${ }^{7-9}$ being lower than in general population and thus reflecting the maturity of the country's tobacco epidemic. At the same time, in the developing countries (eg, Mexico and Philippines), smoking prevalence rates among physicians are much higher than in developed countries being in some cases even higher than in general population. ${ }^{10}{ }^{11}$ In Estonia, smoking among physicians has declined since $1978 .^{12-16}$ Despite being lower than in general 
population, smoking among doctors in Estonia is still higher than among physicians in neighbouring country Finland. ${ }^{14}$

As smoking physicians tend to underestimate smoking as a risk factor, it is important to analyse physicians' smoking and their attitudes towards smoking to involve them in patients' smoking cessation more effectively.

The objective of this study was to explore smoking prevalence and attitudes towards smoking among Estonian physicians in 2002 and 2014.

\section{METHODS}

\section{Study design}

The present study was based on two cross-sectional self-administered postal smoking surveys among Estonian physicians in 2002 and 2014. Initially, the surveys involved all practising physicians in Estonia. In 2002, physicians were drawn from the database of Estonian Health Insurance Fund. In 2014, sample was based on the data from the Estonian Health Care Professionals Registry. In 2002, the questionnaires were mailed to the physicians' workplace. Non-respondents received the questionnaire twice. In 2014, the survey materials were mailed to the physicians' home address. To receive home addresses, data from the Estonian Health Care Professionals Registry were linked with the Population Registry in Estonia. Non-respondents received a reminder letter in a month and another envelope containing survey materials in 2 months.

The questionnaire used in these surveys was originally developed by the WHO and modified according to the Estonian healthcare system. ${ }^{17}$ In 2014, the questions regarding nicotine dependence were added to the questionnaire. Questionnaires concerned individual characteristics, smoking behaviour, attitudes towards and knowledge about tobacco use but also attitudes towards patients' smoking.

The initial survey sample size of all practising physicians in Estonia was 4140 in 2002 and 5666 in 2014 (table 1). Number of respondents was 2747 and 2903, respectively. The crude response rate was $66.3 \%$ in 2002 and $52.0 \%$ in 2014. Corrected response rates (excluding the persons who were unavailable, retired, had wrong address, left Estonia or were dead) were $67.8 \%$ and $53.1 \%$, respectively.

The sample for the present study was restricted to physicians who were younger than 65 years $(n=2549$ in 2002, $\mathrm{n}=2339$ in 2014).

\section{Study variables}

The main outcomes were smoking status and physicians' attitudes towards smoking.

Smoking status was determined by combining answers to several questions concerning smoking and classified as following:

- daily smokers (those who currently smoke every day)

- occasional smokers (those who currently smoke but not every day)

- past smokers (those who have smoked regularly for at least a year but are currently non-smokers)

- never smokers (those who have smoked irregularly less than a year but are not current smokers or have never smoked at all).

For secondary data analysis, smoking status was dichotomised to current smokers (daily and occasional smokers) and non-smokers (past and never smokers). Smoking, in the present study, was defined as smoking cigarettes.

\section{Statements concerning smoking}

Attitudes towards smoking were determined with following seven statements:

- Smoking is very harmful to health.

- It is important to reduce smoking among the population.

- To stop smoking is very hard for many people, so it is better for their health to simply continue smoking.

- Smoking does not damage my health as long as I follow a healthy life style in other fields.

- As many people have smoked for their whole lives until old age and not become ill, smoking is not as dangerous as experts declare.

- To smoke or not to smoke, that is my personal choice.

- Smoking is only dangerous to my health if I smoke more than 10 cigarettes a day.

In the first statement physicians assessed the harmfulness of smoking using 10-point scale ( $10=$ very harmful). Those who had chosen 8-10 were considered as having agreed that smoking is very harmful to the health. Those who had chosen 1-7 were considered as disagreed. In all other statements, possible answers were completely agree/somewhat agree/rather disagree/completely disagree/cannot say. For secondary analysis, answers were dichotomised as agree (completely agree and somewhat agree) and disagree (rather disagree and completely disagree).

Table 1 Initial sample size, number and percentage of respondents, crude and corrected response rates by gender among Estonian physicians in 2002 and 2014

\begin{tabular}{|c|c|c|c|c|c|c|c|c|}
\hline \multirow[b]{2}{*}{ Study year } & \multicolumn{3}{|c|}{ Initial sample size (n (\%)) } & \multicolumn{3}{|c|}{ Number of respondents (n (\%)) } & \multicolumn{2}{|c|}{ Response rate (\%) } \\
\hline & Men & Women & Total & Men & Women & Total & Crude & Corrected \\
\hline 2002 & $846(20.4)$ & 3294 (79.6) & 4140 & $471(17.1)$ & $2276(82.9)$ & 2747 & 66.3 & 67.8 \\
\hline
\end{tabular}


Background variables age, ethnicity, place of residence and medical specialty were considered as confounding factors.

Age was measured in full years.

Ethnicity referred to self-determined national identity and was classified as Estonian/non-Estonian (mainly Russian).

Place of residence was determined as Tallinn (capital of Estonia), other city and other (not urban) settlement.

Medical specialty was determined based on self-reported specialty and was analysed in three groups: family physician, specialist doctor and dentist.

The study methodology follows The Strengthening the Reporting of Observational Studies in Epidemiology Statement guidelines for reporting observational studies.

\section{Data analysis}

Data were analysed separately for men and women. Mean age of respondents with SD was calculated. Distribution (\%) of respondents by background variables and by agreement with seven statements concerning attitudes towards smoking was calculated. $\chi^{2}$ test was used to find differences in background variables and in attitudes towards smoking between 2002 and 2014 . Significance level was set at 0.05 . The age-standardised smoking prevalence with corresponding 95\% CIs was calculated using European standard population. ${ }^{18}$

Multiple binary logistic regression models were used to analyse association of physicians' attitudes towards smoking with study year and smoking status. The models used dichotomised approvement (agreed vs disagreed) as a dependent variable and study year, smoking status, age, ethnicity, place of residence and medical specialty as explanatory variables. Fully adjusted ORs with corresponding 95\% CIs were calculated.

Questionnaires with missing smoking status values $(\mathrm{n}=11)$ were excluded from the analysis. In total, 4877 questionnaires were included to the descriptive analysis ( $\mathrm{n}=2539$ in 2002, $\mathrm{n}=2338$ in 2014). Questionnaires that lacked information concerning background variables and attitudes towards smoking or wherein the statements 'cannot say' was answered were excluded from the $\chi^{2}$ tests and logistic regression models.

Data were analysed using statistical package Stata V.11.

\section{RESULTS \\ Background variables}

An overview of physicians' main background variables is provided in table 2 . The majority of participants were females $(83.6 \%$ in 2002 and $82.5 \%$ in 2014). Among men $50.8 \%$ in 2002 and $38.1 \%$ in 2014 were younger than 45 years $(\mathrm{P}<0.001)$ and among women $45.4 \%$ in 2002 and $38.8 \%$ in 2014 were younger than 45 years old $(\mathrm{P}<0.001)$. Mean age of male physicians was $45.2 \pm 9.8$ in 2002 and $46.9 \pm 10.9$ in 2014 and of female physicians $46.4 \pm 10.2$ in 2002 and $46.7 \pm 11.2$ in 2014 , respectively.

Table 2 Distribution (\%) of respondents by background variables and corresponding $p$ values by gender among Estonian physicians in 2002 and 2014

\begin{tabular}{|c|c|c|c|c|c|c|}
\hline \multirow[b]{2}{*}{ Variable } & \multicolumn{3}{|c|}{ Men } & \multicolumn{3}{|c|}{ Women } \\
\hline & $2002(n=417)$ & $2014(n=409)$ & P value* & $2002(n=2132)$ & $2014(n=1930)$ & P value* \\
\hline Age group & & & $<0.001$ & & & $<0.001$ \\
\hline$<45$ & 50.8 & 38.1 & & 45.4 & 38.8 & \\
\hline$=45$ & 49.1 & 61.9 & & 54.6 & 61.2 & \\
\hline Ethnicity & & & 0.050 & & & 0.748 \\
\hline Estonians & 79.4 & 75.1 & & 84.1 & 83.8 & \\
\hline Non-Estonians & 18.7 & 24.7 & & 15.7 & 16.1 & \\
\hline Missing answer & 1.9 & 0.2 & & 0.3 & 0.1 & \\
\hline Place of residence & & & 0.381 & & & 0.001 \\
\hline Tallinn & 36.5 & 41.3 & & 32.6 & 37.0 & \\
\hline Other city & 47.0 & 44.0 & & 46.0 & 40.6 & \\
\hline Other (rural) & 15.8 & 14.4 & & 20.7 & 22.1 & \\
\hline Missing answer & 0.7 & 0.2 & & 0.7 & 0.2 & \\
\hline Medical specialty & & & 0.460 & & & $<0.001$ \\
\hline Family physician & 9.4 & 9.0 & & 21.0 & 25.3 & \\
\hline Specialist doctor & 77.5 & 74.6 & & 53.8 & 48.2 & \\
\hline Dentist & 9.6 & 12.2 & & 23.3 & 24.7 & \\
\hline Missing answer & 3.6 & 4.2 & & 1.9 & 1.8 & \\
\hline
\end{tabular}

${ }^{*} P$ values demonstrate significant differences $(P<0.05)$ between study years. 
Table 3 The age-standardised prevalence of daily, occasional, past and never smoking ( $\mathrm{n}, \%, 95 \% \mathrm{Cl})$ by gender among Estonian physicians in 2002 and 2014

\begin{tabular}{|c|c|c|c|c|}
\hline \multirow[b]{2}{*}{ Smoking status } & \multicolumn{2}{|c|}{ Men } & \multicolumn{2}{|c|}{ Women } \\
\hline & $\begin{array}{l}2002 \\
n=417\end{array}$ & $\begin{array}{l}2014 \\
n=409\end{array}$ & $\begin{array}{l}2002 \\
n=2122\end{array}$ & $\begin{array}{l}2014 \\
n=1929\end{array}$ \\
\hline Daily & 18.4 (14.5 to 22.3$)$ & 11.8 (8.6 to 15.0$)$ & 6.2 (5.1 to 7.3$)$ & 4.4 (3.5 to 5.3 ) \\
\hline Occasional & 8.4 (5.4 to 11.3$)$ & 3.5 (1.7 to 5.3$)$ & 4.2 (3.3 to 5.2 ) & 1.4 (0.9 to 2.0$)$ \\
\hline Past & 29.8 (25.3 to 34.3$)$ & 26.1 (22.1 to 30.0$)$ & 16.1 (14.5 to 17.8$)$ & 16.5 (14.9 to 18.2$)$ \\
\hline Never & 43.4 (38.4 to 48.5 ) & 58.6 (54.0 to 63.3 ) & 73.4 (71.5 to 75.4$)$ & 77.7 (75.9 to 79.5$)$ \\
\hline
\end{tabular}

\section{Smoking status}

The age-standardised prevalence of daily and occasional smoking was lower, but age-standardised prevalence of never smoking was higher in 2014 than in 2002 (table 3). Age-standardised prevalence of past smoking was similar in 2002 and 2014.

\section{Attitudes towards smoking}

Table 4 summarises physicians' responses regarding attitudes towards smoking in 2002 and 2014. Compared with 2002, in 2014, the attitudes towards smoking were less favourable among both male and female physicians.

\section{Association of physicians' attitudes towards smoking with study year and their smoking status}

Multiple binary logistic regression demonstrated less approving attitudes towards smoking in 2014 than in 2002 (table 5). Compared with 2002, in 2014, male and female physicians agreed significantly more with the statements:

- Smoking is very harmful.

- It is important to reduce smoking among the population.

Compared to 2002, in 2014, male and female physicians agreed significantly less with the statements:

- To stop smoking is very hard for many people, so it is better for their health to simply continue smoking.

- Smoking does not damage my health as long as I follow a healthy life style in other fields.

Compared to 2002, in 2014, only female physicians agreed significantly less with the statements:

- As many people have smoked for their whole lives until old age and not become ill, smoking is not as dangerous as experts declare.

- To smoke or not to smoke, that is my personal choice.

- Smoking is only dangerous to my health if I smoke more than 10 cigarettes a day.

Agreement with all seven statements was associated with smoking status of male and female physicians.

\section{DISCUSSION}

The study analysed smoking and attitudes towards smoking among less than 65-year-old Estonian physicians in 2002 and 2014. Compared with the first study year, smoking prevalence was lower, and attitudes towards smoking were less favourable in 2014. However, smoking physicians had more approving attitudes towards smoking than their non-smoking colleagues.

\section{Smoking status}

The age-standardised prevalence of daily smoking decreased 1.6 times among male and 1.4 times among female physicians from 2002 to 2014 (the age-standardised prevalence of occasional smoking 2.3 and 3.0 times, respectively). This result was expected as smoking among physicians (aged between 23 and 86 years) in Estonia decreased between 1982 and 2014. ${ }^{19} 20$ Among these physicians, age-standardised daily smoking decreased 3.3 times among men and 2.6 times among women ${ }^{19}$ and current smoking 2.8 and 2.4 times, ${ }^{20}$ respectively, over three decades. Smoking rates in Estonia have come down among general population as well. In 2002, daily smoking prevalence was $49.6 \%$ among men and $20.3 \%$ among women. ${ }^{21}$ In 2014, $31.4 \%$ of men and $15.8 \%$ of women were daily smokers. Although Estonia is considered to have reached the mature state in terms of smoking epidemic, the prevalence of daily smoking among physicians in 2014 was still comparable with the rates of daily smoking among Finnish doctors in $2002 .^{14}$

\section{Association between attitudes towards smoking and study year}

The results of this study showed that attitudes towards smoking were less approving in 2014 compared with 2002.

Agreement with the four statements of seven was associated with study year and smoking among male and female physicians. Agreement with the statements that smoking is very harmful and that it is important to reduce smoking among the population was more prevalent in 2014 and less prevalent among smoking physicians. This finding is in accordance with previous international studies showing that compared with non-smokers, smoking physicians agree less that smoking is harmful. ${ }^{4}$

Agreement with the statements that to stop smoking is very hard for many people, so it is better for their health to simply continue smoking and that smoking does not damage my health as long as I follow a healthy life style in other fields was less prevalent in 2014.

Agreement with the three statements of seven was associated with study year among female physicians only. Association was found between study year and agreement with 
Table 4 Attitudes towards smoking (\%) and according p values by gender among Estonian physicians in 2002 and 2014

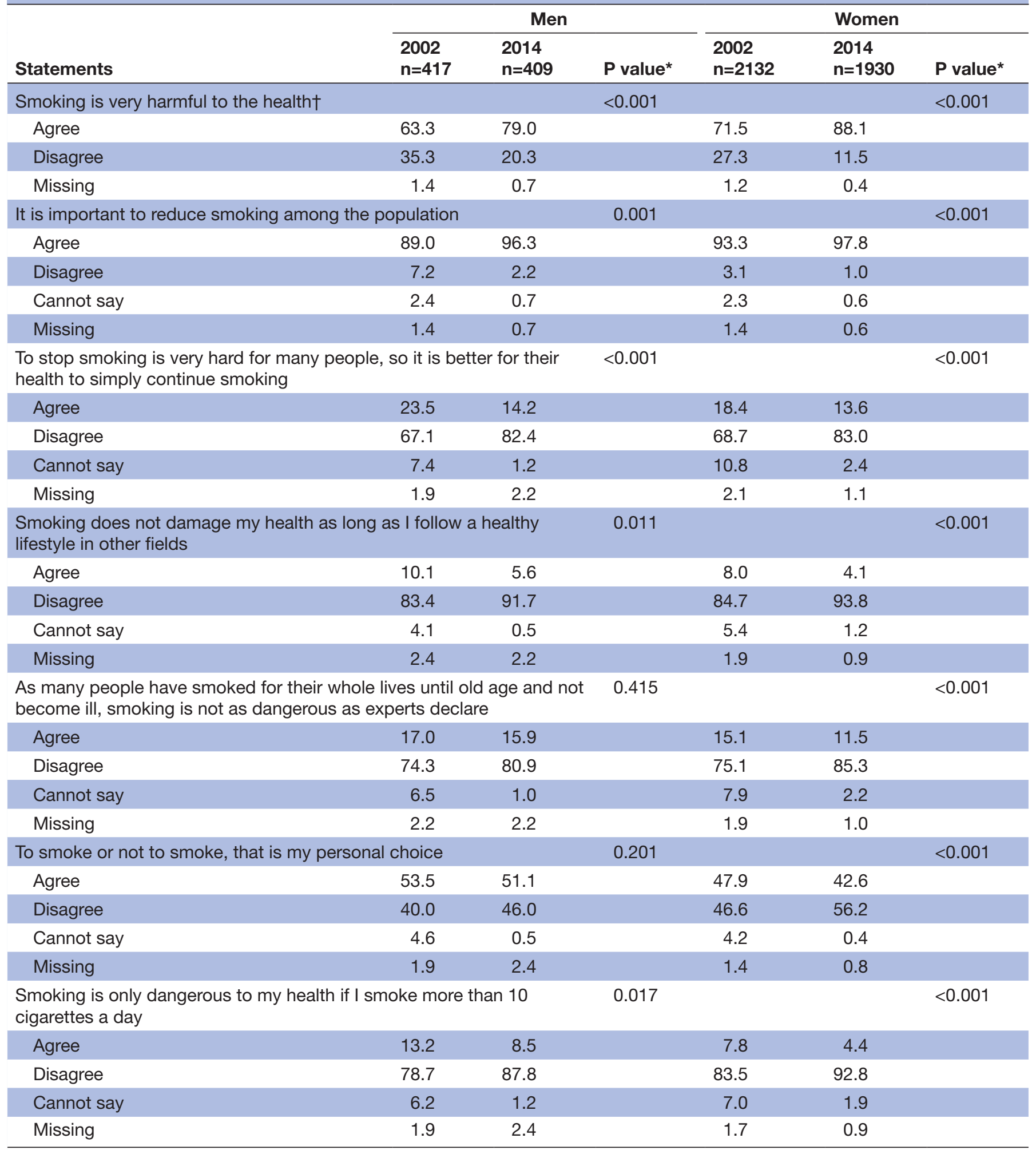

${ }^{*} P$ values demonstrate significant differences $(p<0.05)$ between study years.

†Option 'Cannot say' was not available for this question in the questionnaire.

the statements that as many people have smoked for their whole lives until old age and not become ill, smoking is not as dangerous as experts declare, that to smoke or not to smoke, that is my personal choice and that smoking is only dangerous to my health if I smoke more than 10 cigarettes a day among male physicians. This confirms results from previous studies, according to which smoking behaviour has different patterns among men and women. ${ }^{22} 23$ The difference in opinions between genders might be related to the fact that behaviour of men in general is considered to 
Table 5 Association of physicians' attitudes towards smoking (agreed vs disagreed) with study year and smoking status (OR, $95 \% \mathrm{Cl}$ ) by gender among Estonian physicians in 2002 and 2014

\begin{tabular}{|c|c|c|}
\hline & Men & Women \\
\hline Agree & $\mathrm{OR}^{\star}(95 \% \mathrm{Cl})$ & $\mathrm{OR}^{\star}(95 \% \mathrm{Cl})$ \\
\hline \multicolumn{3}{|c|}{ Smoking is very harmful to the health } \\
\hline 2014 versus 2002 & $2.13(1.51$ to 3.01$)$ & $2.81(2.35$ to 3.36$)$ \\
\hline Smokers versus non-smokers & 0.27 (0.19 to 0.39$)$ & $0.22(0.17$ to 0.27$)$ \\
\hline \multicolumn{3}{|c|}{ It is important to reduce smoking among the population } \\
\hline 2014 versus 2002 & 3.86 (1.69 to 8.80$)$ & 2.96 (1.75 to 5.03$)$ \\
\hline Smokers versus non-smokers & $0.41(0.20$ to 0.84$)$ & $0.27(0.16$ to 0.45$)$ \\
\hline \multicolumn{3}{|c|}{ To stop smoking is very hard for many people, so it is better for their health to simply continue smoking } \\
\hline 2014 versus 2002 & $0.48(0.32$ to 0.72$)$ & $0.62(0.52$ to 0.74$)$ \\
\hline Smokers versus non-smokers & 2.54 (1.67 to 3.86$)$ & 3.46 (2.67 to 4.49$)$ \\
\hline \multicolumn{3}{|c|}{ Smoking does not damage my health as long as I follow a healthy life style in other fields } \\
\hline 2014 versus 2002 & $0.43(0.23$ to 0.79$)$ & 0.48 (0.36 to 0.65$)$ \\
\hline Smokers versus non-smokers & 6.86 (3.90 to 12.06$)$ & 4.56 (3.29 to 6.33$)$ \\
\hline \multicolumn{3}{|c|}{$\begin{array}{l}\text { As many people have smoked for their whole lives until old age and not become ill, smoking is not as dangerous as expert } \\
\text { declare }\end{array}$} \\
\hline 2014 versus 2002 & $0.96(0.63$ to 1.47$)$ & $0.72(0.59$ to 0.87$)$ \\
\hline Smokers versus non-smokers & 5.88 (3.83 to 9.02$)$ & 3.75 (2.88 to 4.89$)$ \\
\hline \multicolumn{3}{|c|}{ To smoke or not to smoke, that is my personal choice } \\
\hline 2014 versus 2002 & $1.01(0.74$ to 1.38$)$ & 0.78 (0.68 to 0.89$)$ \\
\hline Smokers versus non-smokers & 5.87 (3.70 to 9.30$)$ & 4.59 (3.47 to 6.08$)$ \\
\hline \multicolumn{3}{|c|}{ Smoking is only dangerous to my health if I smoke more than 10 cigarettes a day } \\
\hline 2014 versus 2002 & $0.60(0.36$ to 1.00$)$ & 0.51 (0.39 to 0.69$)$ \\
\hline Smokers versus non-smokers & 4.77 (2.90 to 7.84$)$ & 4.32 (3.10 to 6.04$)$ \\
\hline
\end{tabular}

${ }^{*}$ Adjusted for study year, smoking status, age, ethnicity, place of residence and medical specialty.

be more risk prone. ${ }^{24}$ The findings of present study might support the notion that, in Estonia, social acceptability of smoking has decreased, and attention has turned towards prevention and health promotion.

Overall, Estonian physicians' attitudes towards smoking have improved from 2002 to 2014, and the developments concerning decline of smoking in Estonia have created a supportive environment for that. Estonian Tobacco Act, enforced in 2001, renewed in 2005 and amended since with several legal instruments, sets the requirements for creating a smoke-free environment, availability and pricing of tobacco products. Many of Estonian healthcare institutions have joined the network for tobacco-free health services,$^{25}$ and despite the fact that in healthcare institutions in Estonia, smoking is still allowed in designated smoking areas, many hospitals promote reducing smoking among staff, have prohibited smoking everywhere in the hospital area and have declared the hospital smoke-free.

Association between attitudes towards smoking and smoking status

Agreement with all seven statements described above was associated with smoking status of male and female physicians. Most drastically, compared with non-smokers, men who smoked, had six times higher odds to agree that smoking is not as dangerous as experts declare and had seven times higher odds to agree that smoking does not damage health if the person leads an otherwise healthy lifestyle. For smokers, the beliefs that smoking is not dangerous to health might be based on the fact that not all persons who smoke will develop adverse effects of smoking like lung cancer or other smoking-related diseases.

The fact that compared with non-smokers, smoking physicians agreed less that it is important to reduce smoking and believe more that to smoke is person's own choice demonstrates that smoking physicians might feel the need for justification for their own behaviour, especially if they have not developed any smoking-related health problems. Opinions on that matter might also indicate that physicians lessen their role in reducing smoking in the population. According to the worldwide literature, attitudes towards smoking differ by region. In former studies among Italian physicians specialising in public health, $79.6 \%$ considered health professionals as behavioural models for patients, and $96.6 \%$ affirmed that health professionals have a role in giving advice or information about smoking cessation. ${ }^{26}$ In Serbia, $60.7 \%$ of physicians agreed that healthcare professionals serve 
as role models for their patients and public. ${ }^{27}$ However, data from a focus group interview carried out among Armenian doctors revealed that the majority of doctors believed they have no role in patients' quitting. ${ }^{28} \mathrm{Com}-$ pared with Finnish physicians, Estonian physicians were less conscious of their role as healthy lifestyle exemplars in 2002. ${ }^{14}$ Authors then argued that there might be a fear to influence other people's behaviour in Estonia. Results of the present study indicate that the fear still exists.

Although it has been shown before that physicians' beliefs about smoking-related diseases were consistent with medical evidence, ${ }^{15}$ the results of present study showed that physicians who smoke may see smoking more favourably. These opinions can affect smoking cessation activities of the physicians as it has been shown that smokers might not anticipate health problems related to smoking. ${ }^{29}$

\section{Study limitations and strengths}

Possible limitations of this study should be addressed. First, as the study relied on self-reported data, the bias of self-representation should be considered. Second, the corrected response rates of $67.8 \%$ in 2002 and 53.1\% in 2014 should be taken into account. The possibility that smokers prevail among persistent non-respondents may have led to the underestimation of smoking prevalence rates. Third, limitations could be related to the cross-sectional nature of the study thus not providing the opportunity to investigate causal relationships. Also, as only two time points were used, merely a general tendency of smoking prevalence and attitudes towards smoking can be observed. Despite these shortcomings, the survey data provides an excellent opportunity to analyse changes in smoking status and attitudes towards smoking as both surveys were nationwide, the survey methods and questionnaires were similar and physicians are considered a very homogenous cohort in terms of their education.

\section{CONCLUSIONS}

Prevalence of smoking among Estonian physicians was lower in 2014 than in 2002. Although, compared with 2002, attitudes towards smoking were less approving in 2014, it was still apparent that doctors who smoked viewed smoking more favourably.

Continuing monitoring physicians' smoking and attitudes towards smoking will provide information that is useful in development of teaching of tobacco prevention in medical education programmes in Estonia.

Acknowledgements The authors would like to thank Inge Ringmets from the Institute of Family Medicine and Public Health, University of Tartu, for her advice on statistical analysis. We thank the entire team who has been involved in designing and conducting the survey in 2014.

Contributors MP: performed the statistical analysis, interpretation of the data, drafted the manuscript and has been involved in revising the manuscript critically. KP: made a substantial contribution to the conception and the design of the study, interpretation of the data and has been involved in revising the manuscript critically. Both authors have read and approved the final manuscript.
Funding This work was supported by the Estonian Research Council (grant numbers PUT-299 and IUT34-17).

Competing interests None declared.

Ethics approval The surveys in 2002 and 2014 were approved by the Research Ethics Committee of the University of Tartu (decisions no. 87/1 and 235/T-12, respectively).

Provenance and peer review Not commissioned; externally peer reviewed.

Data sharing statement The datasets of 2002 and 2014 are available on request.

Open Access This is an Open Access article distributed in accordance with the Creative Commons Attribution Non Commercial (CC BY-NC 4.0) license, which permits others to distribute, remix, adapt, build upon this work non-commercially, and license their derivative works on different terms, provided the original work is properly cited and the use is non-commercial. See: http://creativecommons.org/ licenses/by-nc/4.0/

(C) Article author(s) (or their employer(s) unless otherwise stated in the text of the article) 2017. All rights reserved. No commercial use is permitted unless otherwise expressly granted.

\section{REFERENCES}

1. World Health Organization. Mortality attributable to tobacco: WHO Global Report. Geneva: WHO, 2012.

2. WHO. Global health risks: mortality and burden of disease attributable to selected major risks. Geneva: WHO, 2009.

3. WHO. The role of health professionals in tobacco control. Geneva: WHO, 2005.

4. Pipe A, Sorensen M, Reid R. Physician smoking status, attitudes toward smoking, and cessation advice to patients: an international survey. Patient Educ Couns 2009;74:118-23.

5. Tang Y, Jiang M, Li DR, et al. Association between awareness of harmful effects of smoking and smoking cessation advice provided by hospital chest physicians in Guangzhou, China: a multiinstitutional cross-sectional survey. Respirology 2013;18:790-6.

6. Doll R, Peto R, Boreham J, et al. Mortality in relation to smoking: 50 years' observations on male British doctors. BMJ 2004;328:1519.

7. Barengo NC, Sandström PH, Jormanainen VJ, et al. Changes in smoking prevalence among Finnish physicians 1990-2001. Eur J Public Health 2004;14:201-3.

8. Smith DR, Leggat PA. An international review of tobacco smoking in the medical profession: 1974-2004. BMC Public Health 2007;7:115.

9. Smith DR, Leggat PA. The historical decline of tobacco smoking among Australian physicians: 1964-1997. Tob Induc Dis 2008;4:13.

10. Abdullah AS, Stillman FA, Yang $L$, et al. Tobacco use and smoking cessation practices among physicians in developing countries: a literature review (1987-2010). Int J Environ Res Public Health 2013;11:429-55.

11. WHO. Tobacco or health: a global status report. Geneva: WHO, 1997.

12. Väärt $E$, Vahtra $M$, Rahu $M$, et al. Eesti arstkonna suitsetamishõlmavuse ankeetküsitlus. Nõukogude Eesti Tevishoid 1979;58:279-81.

13. Rahu M, Raudsepp J. Teine Eesti NSV arstkonna suitsetamislevimuse ankeetküsitlus 1982. aastal. Nõukogude Eesti Tervishoid 1986;65:258-61.

14. Pärna K, Rahu K, Barengo NC, et al. Comparison of knowledge, attitudes and behaviour regarding smoking among Estonian and Finnish physicians. Soz Praventivmed 2005;50:378-88.

15. Pärna K, Rahu K, Rahu M. Smoking habits and attitudes towards smoking among Estonian physicians. Public Health 2005;119:390-9.

16. Lohur L, Pärna K. Arstide suitsetamine, sellealased hinnangud ja tähelepanu pööramine patsientide suitsetamisele. Eesti Arst 2016;95:285-93.

17. Pärna K. Socioeconomic differences in smoking in Estonia: National and international comparisons: University of Helsinki, 2005.

18. Ahmad OB, Boschi-Pinto C, Lopez AD, et al. Age standardization of rates: a new WHO standard.GPE Discussion Paper Series: No. 31. Geneva: WHO, 2001.

19. Pärna K, Põld M, Ringmets I. Trends in smoking behaviour among Estonian physicians in 1982-2014. BMC Public Health 2017;18:55.

20. Pärna K, Põld M, Ringmets I. Physicians' views on the role of smoking in smoking-related diseases: findings from cross-sectional studies from 1982-2014 in Estonia. Tob Induc Dis 2017;15:31.

21. Kasmel A, Lipand A, Markina A. Eesti täiskasvanud elanikkonna tervisekäitumise uuring, kevad 2002. Tallinn: Eesti Tervisekasvatuse Keskus, 2003. 
22. Peters SA, Huxley RR, Woodward M. Do smoking habits differ between women and men in contemporary Western populations? Evidence from half a million people in the UK Biobank study. BMJ Open 2014;4:e005663.

23. Reid RD, Pipe AL, Riley DL, et al. Sex differences in attitudes and experiences concerning smoking and cessation: results from an international survey. Patient Educ Couns 2009;76:99-105.

24. Harris CR, Jenkins M, Glaser D. Gender differences in risk assessment: why do women take fewer risks than men? Judgm Decis Mak 2006;1:48-63.

25. ENSH. Global network for tobacco free health care services. http:// www.ensh.org/members. php?id=48)
26. La Torre G, Saulle R, Unim B, et al. Knowledge, attitudes, and smoking behaviours among physicians specializing in public health: a multicentre study. Biomed Res Int 2014;2014:1-8.

27. Stojanović M, Musović D, Petrović B, et al. Smoking habits, knowledge about and attitudes toward smoking among employees in health institutions in Serbia. Vojnosanit Pregl 2013;70:493-500.

28. Movsisyan NK, Varduhi P, Arusyak H, et al. Smoking behavior, attitudes, and cessation counseling among healthcare professionals in Armenia. BMC Public Health 2012;12:1-9.

29. Rahman MA, Wilson AM, Sanders R, et al. Smoking behavior among patients and staff: a snapshot from a major metropolitan hospital in Melbourne, Australia. Int J Gen Med 2014;7:79-87. 